\title{
Thyroid consequences of the Chernobyl nuclear power station accident on the Turkish population
}

\author{
Rıfat Emral, Mehmet Baştemir, Sevim Güllü and Gürbüz Erdoǧan \\ School of Medicine, Department of Endocrinology and Metabolic Diseases, Ankara University, Ankara, Turkey \\ (Correspondence should be addressed to R Emral, İbn-i Sina Hospital, 10 floor, D block, O6100 Samanpazarı Ankara, Turkey; \\ Email: rifatemral@yahoo.com)
}

\begin{abstract}
Objective: The Chernobyl accident caused widespread effects across Europe and huge areas were radiocontaminated. The major impact of the accident on human health was a sharp increase in childhood thyroid carcinoma and autoimmune thyroid diseases in exposed populations. The thyroidal effects of the Chernobyl accident have been investigated in most European countries, except Turkey. The aim of the current study was therefore to determine the thyroidal consequences of the Chernobyl nuclear power station accident in a selected Turkish population.

Design: This study was designed as a sectional, area study, between October 2000 and March 2001, in two different regions of Turkey. According to the data of the Turkish Atomic Energy Authority, the eastern part of the Black Sea region was the most radiocontaminated area in Turkey at the time of Chernobyl accident, while Middle Anatolia was not seriously affected. Thus, Rize city, which is located in the eastern Black Sea region, served as a study area, and 970 adolescents, living in this region, comprised our study group (group R). On the other hand, Beypazarı, which is located in Middle Anatolia was choosen as the control region, and 710 adolescents living in this location were enrolled into the study as controls (group B).

Methods: During the study, thyroid ultrasounds were performed in all subjects and thyroid volumes were calculated. World Health Organization and International Council for Control of Iodine Deficiency Disorders criteria were used for the determination of goiter. Thyroid fine-needle aspiration biopsy with ultrasound guidance was performed when a nodule was detected. Blood samples for thyroid function tests and thyroid autoantibodies, and urine samples for urinary iodine excretion were collected from all subjects.

Results: Thyroid function tests were similar in both groups, but thyroid volumes were found to be higher in group B $(13.93 \pm 5.04$ vs $17.66 \pm 5.58 \mathrm{ml} ; P<0.001)$. The prevalence of goiter was found to be $28.25 \%$ in group $\mathrm{R}$ and $61.95 \%$ in group $\mathrm{B}(P<0.001)$. Thyroid nodules were determined in $6.28 \%$ of subjects in group $\mathrm{R}$ and $4.22 \%$ of subjects in group $\mathrm{B}(P=0.065)$. No malignant lesions were found in either of the regions. Although the percentage of autoantibody-positive subjects did not differ between groups $(21.25 \%$ in group $\mathrm{R}$ vs $18.72 \%$ in group B), the mean antithyroglobulin level was found to be higher in group R $(63.25 \pm 378.60 \mathrm{vs} 51.97 \pm 333.32 \mathrm{IU} / \mathrm{ml}$; $P<0.001)$ and the mean anti-thyroid peroxidase level was higher in group B $(24.14 \pm 219.09$ vs $48.82 \pm 568.50 \mathrm{IU} / \mathrm{ml} ; P<0.001)$. The iodine status of the selected regions was found to be significantly different (median urinary iodine excretion was $131 \mu \mathrm{g} / \mathrm{l}$ in Rize and $54 \mu \mathrm{g} / \mathrm{l}$ in Beypazarı). Conclusions: Although there was a slight increase in nodule prevalence and thyroid antibody-positive subjects in the study group, it is hard to conclude that Turkey was affected by the Chernobyl accident. These results, at least the significant differences with regard to the prevalence of goiters between groups, may reflect the different iodine status of the selected regions.
\end{abstract}

European Journal of Endocrinology 148 497-503

\section{Introduction}

The Chernobyl nuclear power station accident was on 26 April 1986 and caused a large amount of environmental pollution. A tremendous amount of radioactivity was discharged into the atmosphere. It is fair to say that in terms of the amount of radioactive fall-out, the accident was comparable with a medium-sized nuclear strike (1). Immediately after the accident, the most significant radioisotopes released from the biological point of view were radioiodines. It appears that between 40 and 50 million Curies of ${ }^{131} \mathrm{I}$, 70 million Curies of ${ }^{133} \mathrm{I}$ and 30 million curies of ${ }^{132}$ Tellurium (which decays to ${ }^{132} \mathrm{I}$ ) were released into the environment (2). The well-known public health impact of the Chernobyl catastrophe was the thyroid damage in 
children from the affected areas. Unfortunately, the disaster had an impact on many countries. Regions affected by radioactive fall-out included not only Ukraine itself but also Belarus, Russia, Georgia, Poland, Sweden, Germany, Austria, Hungary, Finland, Norway, Turkey and others. Even such distant countries as the USA and Japan received measurable amounts of radiation (1).

The major effect of the Chernobyl accident on human health demonstrated so far is the very large rise in the incidence of thyroid carcinoma in children, in particular papillary thyroid carcinoma (3-7). Subsequent studies confirmed an association between the appearance of thyroid cancer in those people exposed to the explosion and this appeared to be directly related to the distance from the epicentre of the explosion and inversely related to the age of those exposed $(8,9)$. The thyroid cancer risk varies considerably with time after exposure (10). Children under 5 years of age have five times the risk of older children and about eight times the risk of young adults for the subsequent development of thyroid cancer after radiation exposure $(10,11)$. Beginning in 1990, 4 years after the accident, an impressive increase in the appearance of thyroid cancer in children in the most heavily contaminated regions was noted $(12,13)$.

A marked increase in benign thyroid nodules (14) and autoimmune thyroid disease prevalence were reported after the Chernobyl accident, in addition to thyroid cancers in the contaminated areas (15-18). A comprehensible and well-known consequence of the impact of radiation on the thyroid is lymphocytic thyroiditis (19). Thyroid antigens can be released into the circulation as a result of thyroidal damage after radiation and this may be a trigger for the autoimmune reaction against the thyroid gland $(18,20)$.

Up to now the thyroidal effects of the Chernobyl accident have been investigated in most European countries, except Turkey. So the aim of the current study was to determine the thyroidal consequences of the Chernobyl nuclear power station accident in a selected Turkish population.

In this study, 1680 adolescents between 14 and 18 years of age, living in two different regions (one is known to be radiocontaminated and the other is not) of Turkey were examined to find out whether or not the Chernobyl accident affected Turkey.

\section{Subjects and methods}

This study was designed as a sectional, area study, between October 2000 and March 2001, in two different regions in Turkey. According to the data of the Turkish Atomic Energy Authority, average radiocaesium contamination was found at $900 \mathrm{~Bq} / \mathrm{m}^{2}$, and average radioiodine contamination was found to be as high as $8000 \mathrm{~Bq} / \mathrm{m}^{2}$ in Turkey just after the Chernobyl accident. The estimated radioactivity per person in the Turkish population is $1100 \mathrm{~Bq}(21)$. The eastern part of the Black Sea region was the most radiocontaminated area in Turkey at the time of the Chernobyl accident, while Middle Anatolia was not seriously affected (21).

Hence, Rize city, which is located in the eastern Black Sea region, served as a study area, and 970 adolescents, living in this region, made up our study group (group R). On the other hand, Beypazar,, which is located in Middle Anatolia, near Ankara, the capital, was chosen as the control region, and 710 adolescents living in this location were enrolled into the study as controls (group B). Subjects aged between 14 and 18 years of age were selected for the study since they were all between 0 and 5 years of age at the time of the Chernobyl accident. Table 1 shows the demographic properties of the study and control groups.

During the study, thyroid ultrasounds were performed in all subjects by using real-time B mode, high resolution, General Electric sonography (Hino-shi, Tokyo, Japan) with a $7.5 \mathrm{MHz}$ probe. Thyroid volumes were calculated using the formula (height $(a) \times$ length $(b) \times$ thickness $(\mathrm{c}) \times \pi / 6)$. The volumes of both thyroid lobes were calculated separately and the sum of the volumes of both lobes was accepted as thyroid volume $(22,23)$. For the determination of goiter, World Health Organization and International Council for Control of Iodine Deficiency Disorders criteria were used. Thyroid volume over $13.9 \mathrm{ml}$ in boys and $14.6 \mathrm{ml}$ in girls for 14-year-old adolescents and thyroid volumes over $16.0 \mathrm{ml}$ in boys and $16.1 \mathrm{ml}$ in girls for 15- to 18-yearold adolescents were accepted as goiter (24). Focal, discrete areas, larger than $2 \mathrm{~mm}$ in diameter, and whose echo-density was greater than (hyperechoic), lower than (hypoechoic), or equal to (isoechoic) the rest of the gland were accepted as nodules (25). Thyroid fine-needle aspiration biopsy (FNAB) was performed by ultrasound guidance when a nodule was detected.

\section{Laboratory determinations}

Blood samples for thyroid function tests and thyroid autoantibodies, and urine samples for urinary iodine excretion were collected from all subjects. Both urine and blood samples were frozen immediately and kept at $-80{ }^{\circ} \mathrm{C}$ until assay. Free thyroxine $\left(\mathrm{FT}_{4}\right)$ analysis

Table 1 Demographic properties of the subjects in the study and control regions.

\begin{tabular}{lccc}
\hline & $\begin{array}{c}\text { Rize } \\
(n=970)\end{array}$ & $\begin{array}{c}\text { Beypazar } \\
(n=710)\end{array}$ & $\boldsymbol{P}$ \\
\hline Male/female & $510 / 460$ & $346 / 364$ & $\mathrm{NS}^{\star}$ \\
Mean age (years) & $15.40 \pm 1.04$ & $15.39 \pm 1.13$ & $\mathrm{NS}$ \\
Mean height $(\mathrm{cm})$ & $166.01 \pm 8.52$ & $164.33 \pm 10.15$ & $<0.05$ \\
Mean weight $(\mathrm{kg})$ & $57.43 \pm 9.25$ & $54.13 \pm 11.28$ & $<0.05$ \\
\hline
\end{tabular}

$P$ values; Independent samples' $t$-test; *Fisher's exact test; NS, not significant. 
was based on competitive, direct chemiluminassay by using an ACS:180 (Bayer Corporation, New York, NY, USA) kit and results were calculated as pmol/l. Thyrotropin (TSH) measurements were based on direct immunoassay using the ACS:180 kit. TSH results are expressed as mIU/l. Anti-thyroglobulin (anti-Tg) and anti-thyroid peroxidase (anti-TPO) antibodies were determined as the thyroid autoantibodies. For anti-Tg analysis, immunoradiometric assay with immunoradiometric coated tube (BC 1006-Biocode, Liége, Belgium) kit and for anti-TPO analysis, radioimmunoassay (RIA) with One Step RIA coated tube (BC 1008Biocode) kit were used. Anti-Tg and anti-TPO results are expressed as IU/ml. Anti-Tg levels over $10 \mathrm{IU} / \mathrm{ml}$ and anti-TPO levels over $15 \mathrm{IU} / \mathrm{ml}$ were accepted as autoantibody positivity (15).

Urinary iodine excretion was determined using an enzymatic method, the Sandell-Kalthoff method, with Fisher reactives and by using spectrophotometry (26). Results are expressed as $\mu \mathrm{g} / \mathrm{l}$.

\section{Statistical analysis}

Independent samples' $t$-test was used for comparison of the demographic properties of the study and control groups and for the comparison of thyroid volumes in the two groups. Female/male ratios in the groups and different cytological patterns found due to FNAB results were compared using Fisher's exact test. Urinary iodine excretion, thyroid function tests and thyroid autoantibody levels were compared with the MannWhitney U test. The Chi square test, as appropriate, was also used to compare the goiter prevalence, nodule prevalence, autoantibody positivity prevalence, and ratio of the subjects with urinary iodine excretion under $100 \mu \mathrm{g} / \mathrm{l}$ and under $20 \mu \mathrm{g} / \mathrm{l}$ in groups $\mathrm{R}$ and B. Data are given as means \pm S.D. or median. A $P$ value $<0.05$ was accepted as significant.

\section{Results}

Table 2 shows the results of our comparison of the study and control regions.
In contradiction of the previous studies done in the same areas, the iodine status of the selected regions was found to be significantly different $(27,28)$. Rize city is known to be a seriously iodine-deficient area but the median urinary iodine excretion was found to be $131 \mu \mathrm{g} / \mathrm{l}$ in our study. This shows that the study group had sufficient iodine intake. On the other hand, our control region, Beypazarı, showed mild iodine deficiency with $54 \mu \mathrm{g} / \mathrm{l}$ urinary iodine excretion in the control subjects. The ratio of cases with iodine excretion under $100 \mu \mathrm{g} / \mathrm{l}$ was found to be $22.4 \%$ in Rize and 63.3\% in Beypazar $(P<0.001)$. In addition, $20.1 \%$ of the control subjects had urinary iodine excretion under $20 \mu \mathrm{g} / \mathrm{l}$ in Beypazarı, though only $5.0 \%$ of the study subjects in Rize had severe iodine deficiency, according to their urinary iodine excretion $(P<0.001)$. Hence, study and control regions were also different in the ratio of subjects with iodine deficiency.

Thyroid function tests were similar in both groups, but thyroid volumes were found to be higher in group $\mathrm{B}$, as a reflection of the importance of iodine deficiency in goitregenesis $(13.93 \pm 5.04$ vs $17.66 \pm 5.58 \mathrm{ml}$; $P<0.001)$. Similar results were obtained when the mean thyroid volumes of the different sexes were compared between groups. Mean thyroid volumes of male subjects were found to be $14.13 \pm 4.86 \mathrm{ml}$ in group $\mathrm{R}$ and $18.28 \pm 5.39 \mathrm{ml}$ in group $\mathrm{B}(P<0.001)$. Mean thyroid volumes of female subjects were found to be $13.71 \pm 5.23 \mathrm{ml}$ in group $\mathrm{R}$ and $17.07 \pm 5.70 \mathrm{ml}$ in group $\mathrm{B}(P<0.001)$. Mean thyroid volumes of the male and female subjects were significantly different in group $\mathrm{B}(P<0.01)$, although no sex difference was found in thyroid volumes in group R. The prevalence of goiter was found to be higher and goiter was endemic in both regions, but it was more pronounced in Beypazarı for both sexes. Comparing the two regions, goiter prevalence was found to be $30.8 \%$ in Rize and $70.5 \%$ in Beypazarı for males $(P<0.001)$ and $25.7 \%$ in Rize and 53.4\% in Beypazarı for females $(P<0.001)$. Over all, $28.25 \%$ of the subjects had a goiter in Rize while $61.95 \%$ of the subjects had a goiter in Beypazarı $(P<0.001)$.

Table 2 Comparison of the thyroidal results in the study and control regions.

\begin{tabular}{|c|c|c|c|}
\hline & Rize & Beypazarı & $\boldsymbol{P}$ \\
\hline Urinary iodine excretion $(\mu \mathrm{g} / \mathrm{l})^{\mathrm{d}}$ & 131 & 54 & $<0.001^{\mathrm{a}}$ \\
\hline $\mathrm{FT}_{4}(\mathrm{pmol} / \mathrm{l})^{\mathrm{e}}$ & $17.12 \pm 2.98$ & $16.80 \pm 2.78$ & $\mathrm{NS}^{\mathrm{a}}$ \\
\hline $\mathrm{TSH}(\mathrm{mIU} / \mathrm{l})^{\mathrm{e}}$ & $2.19 \pm 1.31$ & $2.20 \pm 1.79$ & $\mathrm{NS}^{\mathrm{a}}$ \\
\hline Thyroid volumes $(\mathrm{ml})^{\mathrm{e}}$ & $13.93 \pm 5.04$ & $17.66 \pm 5.58$ & $<0.001^{\mathrm{b}}$ \\
\hline Prevalence of goiter (\%) & 28.25 & 61.95 & $<0.001^{\mathrm{c}}$ \\
\hline Prevalence of thyroid nodule (\%) & 6.28 & 4.22 & $=0.065^{\mathrm{c}}$ \\
\hline Anti-Tg (IU/ml $)^{\mathrm{e}}$ & $63.25 \pm 378.60$ & $51.97 \pm 333.32$ & $<0.001^{a}$ \\
\hline Anti-TPO (IU/ml) & $24.14 \pm 219.09$ & $48.82 \pm 568.50$ & $<0.001^{a}$ \\
\hline Antibody-positive subjects (\%) & 21.25 & 18.72 & $\mathrm{NS}^{\mathrm{C}}$ \\
\hline
\end{tabular}

${ }^{a}$ Mann-Whitney $U$ test; ' Independent samples' $t$-test; ' ${ }^{\text {C }}$ hi square test; NS, not significant.

${ }^{\mathrm{d}}$ Data are the median; ${ }^{\mathrm{e}}$ means \pm S.D. 
Thyroid nodules were determined in 61/970 (6.28\%) of the subjects in Rize and 30/710 (4.22\%) of the subjects in Beypazarı. Thyroid nodule prevalance was higher in the study group but the difference was not statistically significant, although it was close to significance $(P=0.065)$. Table 3 shows the cytological results of FNAB in the subjects.

As shown in Table 3, colloidal nodules were more frequent in the study group. Although the difference did not reach significance, the frequency of Hashimoto's thyroiditis was prominent in the study group. On the other hand, no malignant lesion was found in either of the regions.

Thyroid autoantibody levels were different between the study and control groups. Although the percentage of autoantibody-positive subjects did not differ between the groups, the mean anti-Tg level was found to be higher in group R $(63.25 \pm 378.60$ vs $51.97 \pm 333.32 \mathrm{IU} / \mathrm{ml} ; \quad P<0.001)$ and mean antiTPO level was higher in group B $(24.14 \pm 219.09$ vs $48.82 \pm 568.50 \mathrm{IU} / \mathrm{ml} ; P<0.001)$. The percentage of anti-Tg-positive subjects was found to be $20.58 \%$ in group R and $18.43 \%$ in group B, and that of antiTPO-positive subjects was $4.83 \%$ in group $\mathrm{R}$ and $4.39 \%$ in group B. Both anti-Tg and anti-TPO positivity were determined in $4.04 \%$ of group $\mathrm{R}$ and in $4.11 \%$ of group B. In addition, $21.25 \%$ of the subjects in group R and $18.72 \%$ of the subjects in group B had thyroid autoantibody positivity (anti-Tg and/or antiTPO). The difference in thyroid antibody positivity in the groups was not statistically significant.

As expected, thyroid autoantibody positivity was higher among girls when compared with boys in both regions, but the difference was not significant (in Rize $15.74 \%$ for boys, $27.44 \%$ for girls; in Beypazarı $11.37 \%$ for boys, $25.69 \%$ for girls). Comparing the percentage of autoantibody-positive males and females, there was no difference between the groups. Mean anti-Tg and anti-TPO levels were found to be higher in females in the study and control regions, and the difference was significant. The mean anti-Tg levels were found to be $99.07 \pm 474.09 \mathrm{IU} / \mathrm{ml}$ in females and $31.45 \pm 271.14 \mathrm{IU} / \mathrm{ml}$ in males in group $\mathrm{R}$ $(P<0.001)$, and $82.28 \pm 365.11 \mathrm{IU} / \mathrm{ml}$ in females

Table 3 Cytological results of FNAB in study and control subjects.

\begin{tabular}{lccc}
\hline & Rize & Beypazarı & $\boldsymbol{P}$ \\
\hline Colloidal nodule & 31 & 2 & $<0.001$ \\
Regressive changes & 15 & 15 & NS \\
Cystic regressive changes & 5 & 7 & NS \\
Hashimoto's thyroiditis & 6 & 1 & NS \\
Hemorrhagic cyst & 0 & 2 & NS \\
Hyperplastic nodule & 1 & 1 & NS \\
Inadequate material & 3 & 2 & NS \\
Total & 61 & 30 & NS \\
\hline
\end{tabular}

$P$ values; Fisher's exact test; NS, not significant. and $10.15 \pm 69.63 \mathrm{IU} / \mathrm{ml}$ in males in group $\mathrm{B}$ $(P<0.001)$. The mean anti-TPO level was found to be $35.32 \pm 282.58 \mathrm{IU} / \mathrm{ml}$ in females and $8.93 \pm$ $72.99 \mathrm{IU} / \mathrm{ml}$ in males in group $\mathrm{R}(P<0.01)$, and $67.03 \pm 577.34 \mathrm{IU} / \mathrm{ml}$ in females and $10.75 \pm 124.16$ in males in group $\mathrm{B}(P<0.001)$.

\section{Discussion}

The Chernobyl nuclear power station accident has entered the chronicles of the 20th century as the worst technogenic environmental disaster in history (1). It caused widespread effects across Europe and huge areas were radiocontaminated. Although ${ }^{131} \mathrm{I}$ has a half-life of only 8 days, it caused large radiation exposures during the weeks immediately following the accident. As a consequence of inhaling aerosols containing ${ }^{131} \mathrm{I}$, the thyroid glands of the exposed population are thought to be affected seriously; especially those who were children. Because iodine is collected in the thyroid gland, these children have developed chronic inflammation of the thyroid. Although the inflammation itself produced no symptoms, it has started to give rise to a wave of cases of autoimmune thyroid diseases $(15-18)$. On the other hand, a sharp increase in childhood thyroid cancer was also observed in the years following the accident $(1,3-5,12,13)$.

Turkey is closer to the place of the accident than most European countries but fortunately the disaster did not affect the whole country except the north eastern part, the Black Sea region (21). This is the first report investigating the probable thyroidal consequences of the Chernobyl accident in Turkey, by comparing 14- to 18-year-old adolescents, who were between 0 and 5 years of age at the time of the accident, living in the north eastern region with their age- and sex-matched controls living in Middle Anatolia.

According to our results, the iodine status of the selected regions were different from each other. Compatible with previous studies, the study area, Rize city, is known to be an iodine-deficient area with $14 \mu \mathrm{g} / \mathrm{l}$ urinary iodine concentrations $(27,28)$. Hence we selected a town which was also known to be an iodine-deficient area for comparison. To our surprise, however, we found that the median urinary iodine excretion in the study region was high and the area was found to be iodine sufficient with a median urinary iodine excretion of $131 \mu \mathrm{g} / \mathrm{l}$. This is probably due to mandatory salt iodinization which was started in 1999 in Turkey. Mandatory salt iodinization caused an increase in urinary iodine excretion in Beypazarl, our control region, as well, when comparing it with previous studies $(27,28)$, but it was still a mildly iodine-deficient area.

The thyroid function tests were similar in both regions. However, goiter prevalence and the mean thyroid volumes in the whole group and in both sexes were all found to be lower in Rize, in the study group. 
However, previous studies investigating the probable effects of the Chernobyl accident have demonstrated that thyroid enlargement is much more frequent in the exposed population (16). Our results seem to be a reflection of higher median urinary iodine excretion in the study population. It is well known that iodine deficiency is the most important factor for goitregenesis (27-29). The difference in median urinary iodine excretion has led to the difference in goiter prevalence between the regions. Hence the Chernobyl accident is not likely to have a role in goitregenesis in the contaminated area.

Although the goiter prevalence in Rize was lower when compared with Beypazarı, goiter is still endemic in Rize (28.25\%), as in Beypazarı (61.95\%). But the ratios show that goiter prevalence has been decreasing in the region compared with previous data $(27,28)$. Studies on the population exposed to the radioactivity showed that not only the prevalence of thyroid cancer but also the prevalence of benign thyroid nodule increased after the exposure (30-33). Thyroid nodule prevalence was higher in Rize than in Beypazarı, but the difference was not statistically significant $(6.28 \%$ vs $4.22 \% ; P=0.065)$. Hence it is difficult to claim that radioactivity played a causative role on nodule development in our study group. On the other hand, in different studies, thyroid nodule prevalence was found to be between $0.055 \%$ and $1.8 \%$ in school-age children $(34,35)$. These prevalences were much lower compared with our results. Nodule prevalence was also high in our control group. Thyroid nodules are more frequent in iodine deficiency and, beside TSH, iodine is one of the best known classic factors that control thyrocyte proliferation (36). High thyroid nodule prevalences in both regions may be the result of the severe to mild iodine deficiency in the regions in earlier times. Previous reports showed that the Black Sea region was a severely iodine-deficient area, and Middle Anatolia was a mildly iodine-deficient area before mandatory iodinization in Turkey $(27,28)$.

No malignant lesion was determined in the study or control subjects according to FNAB results. Previous studies have demonstrated a very large rise in the incidence of thyroid carcinoma in children after Chernobyl $(3-7)$. From this point of view, we have difficulty in accusing the Chernobyl accident of the relatively higher thyroid nodule ratio determined in the study group. Essentially, nodule formation, in particular colloidal nodule formation, can develop in individuals living in an iodine-deficient area after iodine prophylaxis (37) and our study group is a good example.

Pacini et al. (15) found a significantly higher prevalence of anti-Tg and/or anti-TPO autoantibodies in individuals exposed to radiation after Chernobyl. Kasatkina et al. (16) demonstrated a marked increase in the frequency of autoimmune thyroid disease in an iodine-deficient population of children exposed to low radioactive fall-out compared with an even more iodine-deficient population of children who were not so exposed. In an other study (17), the prevalence of circulating thyroid autoantibodies in the contaminated area was found to be fourfold higher than the uncontaminated neighbouring area. On the basis of autoimmune thyroid diseases, it is again hard to conclude that Chernobyl has had an important role in the development of the autoimmune thyroiditis found in our study. Mean anti-Tg levels were significantly higher in the study subjects $(63.25 \pm 378.60$ vs $51.97 \pm 333.32 \mathrm{IU} / \mathrm{ml}$ ), but mean anti-TPO levels were significantly higher in the controls $(24.14 \pm 219.09$ vs $48.82 \pm 568.50 \mathrm{IU} / \mathrm{ml})$. Anti-Tg autoantibodies may be the result of the high iodine intake in the study group $(38,39)$, because excess iodine intake may cause autoimmune thyroid disease by interacting with the immune system (40). But it is difficult to explain the higher anti-TPO level in the control group. The prevalence of thyroid autoantibody positivity was only slightly higher in the study group. In spite of the fact that the percentage of autoantibody-positive subjects was higher in females than in males, the difference was not significant in any region. On the contrary, both mean anti-Tg and anti-TPO levels were found to be significantly higher in female subjects, but there was no difference between the regions. It is well known that autoimmune thyroid diseases are more frequent in females (41). So, no important rise in autoimmune thyroid disease prevalence was determined in the radiocontaminated region in this study. A higher frequency of Hashimoto's thyroiditis might also be the result of higher iodine intake in our study subjects. In their study, Lind et al. (42) pointed out that lymphocytic thyroiditis was more frequent in the iodinesufficient areas (42).

In conclusion, although there was a slight increase in nodule prevalence and thyroid antibody-positive subjects in the study group, it is difficult to conclude that Turkey was affected by the Chernobyl nuclear power station accident. These results, at least the significant differences on goiter prevalence between the groups, may be caused by the different iodine status of the selected regions. As a result of iodinized salt prophylaxis in Turkey, the iodine status of the regions has been changed. However, a striking result of the present study was that iodine deficiency and endemic goiter are still present and constitute an important health problem, despite 2 years of iodinized salt prophylaxis in Turkey.

\section{Acknowledgements}

We are grateful to our nurse Suzan Durmaz for her efforts during the area study. We also thank our laboratory workers for the hormonal analysis and Yasemin Genç for her assistance in statistical analysis. 


\section{References}

1 Shcherbak YM. Ten years of the Chernobyl era. Scientific American $199627444-49$

2 Tuttle RM \& Becker DV. The Chernobyl accident and its consequences: update at the Millenium. Seminars in Nuclear Medicine 200030 133-140.

3 Baverstock KF, Egloff B, Pinchera A, Ruchti C \& Williams D. Thyroid cancer after Chernobyl. Nature 1992359 21-22.

4 Jacob P, Kenigsberg Y, Goulko G, Buglova E, Gering F, Golovneva A et al. Thyroid cancer risk in Belarus after Chernobyl accident: comparison with external exposures. Radiation and Environmental Biophysics 200039 25-31.

5 Pacini F, Vorontsova T, Demidchik EP, Molinaro E, Agate L, Romei $\mathrm{C}$ et al. Post-Chernobyl thyroid carcinoma in Belarus children and adolescents: comparison with naturally occurring thyroid carcinoma in Italy and France. Journal of Clinical Endocrinology and Metabolism 199782 3563-3569.

6 Jacob P \& Goulko G. Thyroid cancer risk to children calculated. Nature 1998392 31-32.

7 Williams ED. Fallout from Chernobyl. Thyroid cancer in children increased dramatically in Belarus. British Medical Journal 1994 121298.

8 Thompson DE, Mabuchi K, Ron E, Soda M, Tokunaga M, Ochikubo $\mathrm{S}$ et al. Cancer incidence in atomic bomb survivors. Part II. Solid tumors, 1958-1987. Radiation Research 1994137 17-67.

9 Socolow WL, Hashizume A, Neriishi S \& Niitani R. Thyroid carcinoma in man after exposure to ionizing radiation. A summary of the findings in Hiroshima and Nagasaki. New England Journal of Medicine 1963268 406-410.

10 Ron E, Lubin JH, Shore RE, Mabuchi K, Modan B, Pottern LM et al. Thyroid cancer after exposures to external radiation: a pooled analysis of seven studies. Radiation Research 1995141 259-277.

11 Shore R. Issues and epidemiological evidence regarding radiation-induced thyroid cancer. Radiation Research 1992131 98-111.

12 Becker DV, Robbins J, Beebe GW, Bouville AC \& Wachholz BW. Childhood thyroid cancer following the Chernobyl accident: a status report. Endocrinology and Metabolism Clinics of North America $199625197-211$.

13 Antonelli A, Miccoli P, Derzhitski VE, Panasiuk G, Solovieva N \& Baschieri L. Epidemiologic and clinical evaluation of thyroid cancer in children from the Gomel region (Belarus). World Journal of Surgery $1996 \mathbf{2 0} 867-871$.

14 Nikiforov YE, Nikiforova MN, Gnepp DR \& Fagin JA. Prevalence of mutations of ras and p53 in benign and malignant thyroid tumors from children exposed to radiation after the Chernobyl nuclear accident. Oncogene 199613 687-693.

15 Pacini F, Vorontsova T, Molinaro E, Kuchinskaya E, Agate L, Shavrova E et al. Prevalence of thyroid autoantibodies in children and adolescents from Belarus exposed to the Chernobyl radioactive fallout. Lancet $1998 \mathbf{3 5 2} 763-766$

16 Kasatkina EP, Shilin DE, Rosenbloom AL, Pykov MI, Ibragimova GV, Sokolovskaya VN et al. Effects of low level radiation from Chernobyl accident in a population with iodine deficiency. European Journal of Pediatrics $1997 \mathbf{1 5 6}$ 916-920.

17 Vermiglio F, Castagna MG, Volnova E, Lo Presti VP, Moleti M, Violi MA et al. Post-Chernobyl increased prevalence of humoral thyroid autoimmunity in children and adolescents from a moderately iodine-deficient area in Russia. Thyroid 19999 $781-786$.

18 Vykhovanets EV, Chernyshov VP, Slukvin II, Antipkin YG, Vasyuk AN, Klimenko HF et al. 131-I dose-dependent thyroid autoimmune disorders in children living around Chernobyl. Clinical Immunology and Immunopathology 199784 251-259.

19 Poverennyi AM, Shinkarkina AP, Vinogradova IuE, Beziaeva GP, Podgorodnichenko VK \& Tsyb AF. The probable sequelae of thyroid damage from radioactive iodine during the Chernobyl accident. Radiatsionnaia Biologia, Radioecoogia/Rossiiskaia Akademiia Nauk $199636632-640$.

20 Hancock SL, Cox RS \& McDougall IR. Thyroid diseases after treatment of Hodgkin's disease. New England Journal of Medicine 1991325 599-605.

21 Başbakanlık Türkiye Atom Enerjisi Kurumu Raporu. Türkiye’de Cernobil Sonrası Radyasyon ve Radyoaktivite Ölcümleri, pp 1-58. Nisan, Ankara: Basbakaalik Matbaasi, 1988.

22 Brunn J, Blocjk U, Ruf J, Bos I, Kunze WP \& Scriba PC. Volumetrie der schilddrusenlappen mittels real-time-sonographie. Deutsches Medizinisches Journal 1981287 1206-1207.

23 Takalo RM, Makarainen HP \& Jaakkola RK. Thyroid gland volume and echo structure in 13-year-old children in northen Finland. Acta Endocrinologica $1991 \mathbf{1 2 4} 238-244$.

24 WHO/ICCIDD, Recommended normative values for thyroid volume in children aged 6-15 years. Bulletin of the World Health Organization $19957595-97$.

25 Blum M \& Yee J. Method of performing ultrasonography of the neck. In Thyroid Ultrasound and Ultrasound Guided FNA Biopsy. pp 35-58. Ed. HJ Baskin. Boston: Kluwer Academic Publishers, 2000.

26 Szybinski Z, Nauman J, Gembicki M, Rybakowa M, Huszno B, Golkowski $\mathrm{F}$ et al. Principles, main goals and methods of the nationwide program: 'Investigations on iodine deficiency and model of iodine prophylaxis in Poland'. Endokrynologia Polska $199344235-248$

27 Erdoğan G, Erdoǧan MF, Delange F, Sav H, Güllü S \& Kamel N. Moderate to severe iodine deficiency in three endemic goiter areas from the Black Sea region and the capital of Turkey. European Journal of Epidemiology $2000 \mathbf{1 6} 1131-1134$.

28 Erdoğan G, Erdoğan MF, Emral R, Baștemir M, Sav H, Haznedaroğlu D et al. Iodine status and goitre prevalence of Turkey before mandatory iodization. Journal of Endocrinological Investigation $200225224-228$.

29 Vitti P, Martino E, Aghini-Lombardi F, Rago T, Antonangeli L, Maccherini $\mathrm{D}$ et al. Thyroid volume measurement by ultrasound in children as a tool for the assessment of mild iodine deficiency. Journal of Clinical Endocrinology and Metabolism $1994 \mathbf{7 9}$ $600-603$.

30 Nikiforov Y, Gnepp DR \& Fagin JA. Thyroid lesions in children and adolescents after Chernobyl disaster: implication for the study of radiation tumorigenesis. Journal of Clinical Endocrinology and Metabolism $1996 \mathbf{8 1}$ 9-14.

31 Ito M, Yamashita S, Ashizawa K, Namba H, Hoshi M, Shibata Y et al. Childhood thyroid diseases around Chernobyl evaluated by ultrasound examination and fine needle aspiration cytology. Thyroid 19955 365-368.

32 Schneider AB, Ron E, Lubin J, Stovall M \& Gierlowski TC. Dose-response relationship for radiation induced thyroid cancer and thyroid nodules: evidence for the prolonged effects of radiation on the thyroid. Journal of Clinical Endocrinology and Metabolism $199377362-369$.

33 Sugenoya A, Asanuma K, Hama Y, Masuda H, Skidanenko GS, Anatoliebna AT et al. Thyroid abnormalities among children in the contaminated area related to the Chernobyl accident. Thyroid $1995529-33$.

34 Raab SS, Silverman JF, Elsheikh TM, Thomas PA \& Wakely PE. Pediatric thyroid nodules: disease demographics and clinical management as determined by fine needle aspiration biopsy. Pediatrics 199595 46-49.

35 Jaksic J, Dumic M, Filipovic B, Ille J, Cvijetic M \& Gjuric G. Thyroid diseases in a school population with thyromegaly. Archives of Disease in Childhood 199470 103-106.

36 Sadoul JL. Genesis of thyroid nodules. Physiological and pathological mechanisms, clinical implications. Annales d'Endocrinologie $1995 \mathbf{5 6} 5-22$.

37 Kanno J, Onodera H, Furuta K, Maekawa A, Kasuga T \& Hayashi Y. Tumor-promoting effects of both iodine deficiency and iodine excess in the rat thyroid. Toxicologic Pathology $199220226-235$. 
38 Gardas A. The influence of iodine on the immunological properties of thyroglobulin and its immunological complexes. Autoimmunity $19919331-336$.

39 Papanastasiou L, Alevizaki M, Piperingos G, Mantzos E, TseleniBalafouta S \& Koutras DA. The effect of iodine administration on the development of thyroid autoimmunity in patients with nontoxic goiter. Thyroid $200010493-497$.

40 Boyages SC, Bloot AM, Maberly GF, Eastman CJ, Li M, Qian QD et al. Thyroid autoimmunity in endemic goiter caused by excessive iodine intake. Clinical Endocrinology 198931 453-465.
41 Chiovato L, Lapi P, Fiore E, Tonacchera M \& Pinchera A. Thyroid autoimmunity and female gender. Journal of Endocrinological Investigation 199316 384-391.

42 Lind P, Langsteger W, Molnar M, Gallowitsch HJ, Mikoscch P \& Gomez I. Epidemiology of thyroid diseases in iodine sufficiency. Thyroid 19998 1179-1183.

Received 20 June 2002

Accepted 23 January 2003 